NBER WORKING PAPER SERIES

\author{
MICROECONOMIC ASPECTS OF PRODUCTIVITY \\ GROWTH UNDER IMPORT SUBSTITUTION: \\ TURKEY
}

Anne 0. Krueger

Baran Tuncer

Working Paper No. $\underline{52}$

\author{
NATIONAI BUREAU OF ECONOMIC RESEARCH \\ 1050 Massachusetts Avenue \\ Cambridge MA 02138
}

August 1980

\begin{abstract}
The authors wish to thank the National Science Foundation for its support of the research underlying this paper under Grant No. S0C77-25776. We are also grateful to the Turkish Industrial Development Bank for its assistance in the project. We have benefited greatly from the comments and suggestions of Professor James M. Henderson. Ebbe Yndgaard, Claus Vastup, Martin Paldam, and other members of the faculty at Aarhus University provided helpful comments and suggestions at an early stage of the research, as did colleagues at Bogazici University, including especially Maxwell Fry. Members of the Trade and Development Workshops at the University of Chicago made many useful comments on an earlier draft of this paper. Zafar Ahmed, Roger Johnson, Inci Mubarek, Lale Tezel, and Paitoon Wiboonchutikula provided research assistance at various stages of the project. The research reported here is part of the NBER's research program in International Studies. Any opinions expressed are those of the authors and not those of the National Bureau of Economic Research.
\end{abstract}




\section{Microeconomic Aspects of Productivity Growth Under Import Substitution: Turkey}

\section{$\underline{\text { ABSTRACT }}$}

This paper assesses the empirical relevance of "dynamic" factors in industrialization in developing countries. Using data from a sample of 91 firms, rates of growth of output per unit of input are calculated. It is shown that there is little basis, at least with regard to Turkish experience, to the notion that non-traditional industries are in some sense more "dynamic" than traditional industries. 


\section{MICROECONOMIC ASPECTS OF PRODUCTIVITY GROWTH}

UNDER IMPORT SUBSTITUTION: TURKEY

Anne 0. Krueger and Baran Tuncer*

Are there dynamic factors in the growth of new Industries? What is learning by dolng, and how Important is 1t? How much truth 1 s there to the Infant Industry argument in any of 1 ts forms? What 1s the relationship between the entry, growth, and efficiency of Individual firms and that of the Industries to which they belong? How does that efficlency compare with levels in other countries? What is the relationship between policy measures, such as cholce of trade pollcy and trade pollcy-instruments, and rates of growth and of Input and output?

These questions have been debated endlessly at an analytical level, and yet final resolution of them hinges crucially on empirical analysis of the orders of magnitude Involved. For, the absence of externalities can be proven only empirically. And, if there are externalities of the type posited by defenders of "dynamic" arguments, not only their existence but also their magnitude is important. It 1s the purpose of this paper to provide some evidence, based on the experfence of Turkish manufacturing Industry, on which to form a fudgment as to quantitative answers to some of these questions. Naturally, it 1 s hoped that similar research for other

* The authors wish to thank the National Sclence Foundation for 1ts support of the research underlying this paper under Grant No. S0C77-25776. We are also grateful to the Turkish Industrial Development Bank for 1ts assistance in the profect. We have benefited greatly from the comments and suggestions of Professor James M. Henderson. Ebbe Yndgaard, Claus Vastup, Martin Paldam, and other members of the faculty at Aarhus University provided helpful comments and suggestions at an early stage of the research, as did colleagues at Bogazic1 Untversity, Including espectally Maxwell Fry. Members of the Trade and Development Workshops at the Untversity of ChIcago made many useful comments on an earller draft of this paper. Zafar Ahmed, Roger Johnson, Inc1 Mubarek, Lale Tezel, and Paltoon Wiboonchutikula provided research assistance at various stages of the project. The research reported here is part of the NBER's program in International studies. Any opinions expressed are those of the author and not those of the National Bureau of Economic Research. 
countries will be spurred by our findings, and that the research represents a first step toward a more general assessment of the relevant parameters.

A first section contains a brief outline of the lssues and the analytical debate. A second then covers some sallent aspects of Turkey's economfc development and Import substitution policies as they relate to interpretation of the results. The third section outlines the techniques of measurement employed and the data used. The fourth section presents the empirical findings. A final section assesses the results and sketches some avenues for future research.

I. INFANT INDUSTRY ARGUMENTS AND TRADE POLICY

In their quest to spur rapid economic growth, most developing countries have adopted policies generally termed "Import substitution." Detalls of polfcy instruments have varled, but a major thrust has been to employ highly restrictive trade policy instruments designed to encourage the development of domestic manufacturing industry.

Proponents of these policles generally concede that they are in violation of the precepts of neoclassical economics in terms of effictent resource allocation. Generally, however, it is contended that some sort of "dynamic" effects are present that w1ll permit more rap 1d long-run growth if the short-run costs of starting these industries are borne. Analysts have searched within the neoclassical framework for bases on which such dynamic elements might exist, and most have been skeptical. ${ }^{1}$

1. See, for example, Baldwin's analysis of the ctrcumstances under which infant industry externalit les might be present, and optimal policy In those Instances. See also Bhagwat1, Ch. VII, for an emuneration of other possible dynamic considerations favoring the development of new Industry through import substitution. 
Arrow's "Learning by Doing" provides one line of defense, although even that argument, which hinges on cumulative output as the source of learning experience, does not provide a rationale for favoring the development of one industry over another without emplrlcal evidence that learning might be faster in the favored Industry. Worse yet, If learning were Industry speciflc, learning by doing would provide at best an argument for selectlve Industrial development, rather than the across-the-board, destined-forthe-domestic-market varlety that has been assoclated with import substitution policles. Indeed, Industrles that had learned would generally be expected to become exporters of thelr output, rather than to remaln behind a wall of tariff protection Into the indefinite future.

It would appear that if there is a dynamic argument, no matter what Its nature, it must somehow assert that industry (or firm) costs w111 fall over t1me. That, in turn, can only happen if rates of growth of output per unit of input assoclated with "infant" firms and industries are more rapid than those assoclated with currently unprotected (and hence more efficlent in the ecconomic sense) lines of activity. ${ }^{1}$ Evidence of such higher growth rates would be necessary, but not sufficient, to provide a defense for 1mport subst1tution, both because more rapld growth 1s not per se evidence of actual overtaking either absolutely or in sufficlent magnitude

1 Even then, for public pollcy to encourage such industries, it would be necessary to stipulate a reason why such activities were not privately profitable. 
to repay foregone alternatives ${ }^{1}$ and because alternative policies might generate the same sorts of growth performance without incurring the costs associated with high rates of protection to sheltered domestic markets. ${ }^{2}$

It may also be noted that at constant International prices, increasing output per unit of quantitative input in an activity is a necessary prerequisite for permitting rising real incomes to factors employed in that activity, consistent with maintaining comparative advantage. ${ }^{3}$ Alternatively, If factors in a particular industry are earning a normal rate of return, the competitive position of the industry can improve (at constant prices) only with increases in output per physical unft (i.e., quality unadjusted) of input. Thus, any "dynamic" shifts in comparative advantage (other than those arising from changing factor endowments) would presumably be reflected in rates of growth of output per unit of input above the rate of growth of real factor payments.

In this paper, therefore, focus is upon output per unit of input In vartous lines of endeavor in Turkish manufacturing industry and its behavior over time. First, however, attention must be given to those aspects of Turkish economic development and policies relevant for interpreting the results.

1 The rate of growth of output per unit of input of the "Infants" would have to exceed rates in other sectors for a sufficiently long time for overtaking to occur, and in addition, by an amount sufficient to repay investment. That 1s, the foregone costs of undertaking the higher-cost activity would have to yield at least as high a rate of return as alternative investments.

2 It can even be argued that sheltering domestic firms may reduce their incentives for efficiency by enough to offset, or even more than offset, the potential learning gains. In that case, the dynamic argument could in principle be correct, but false when carried out under restrictive trade policies.

3 For the economy as a whole (given international prices or autarky), real incomes to factors can rise only with growth of output per unit of input or with the transfer of resources from less effictent to more effictent uses. 


\section{IMPORT SUBSTITUTION IN TURKEY}

Since the 1930's, Turkey has generally followed a polfcy of protecting domestic industry against foreign competition and of encouraging the development of new industries. ${ }^{1}$ In the period prior to World War II, the chief instrument was the establishment of public enterprises which began producing a variety of industrial products. Although public enterprises have continued to be important within the manufacturing sector, their relative importance has declined somewhat over time. Public sector enterprises accounted for 35 percent of value added in Turkish manufacturing industry in 1963 and for 31 percent by 1976 .

After the Second World War, there was a period of rapid expansion which lasted until about 1953, as prewar trade channels were reopened and foreign assistance permitted an increased rate of investment. Thereafter, severe foreign exchange difficulties led to high levels of protection and stringent import licensing controls for the balance of the decade. This resulted in large part from an inflation rate which exceeded 20 percent annually from 1955 to 1958 (at a fixed exchange rate), and partly for other reasons. From 1955 unt11 about 1960, therefore, the domestic market was highly sheltered, but it is arguable how much of the encouragement to new firms and industries was deliberate, and how much was the side effect of measures intended to protect the overvalued exchange rate and restrict imports.

1 For a more detalled account of Turkish polfcies affecting import substitution in the industrial sector, see Krueger. 
After 1960, when a revolution overthrew the government and led to a new constitution, planning was a key tenet of Turkish economic development. In all the plans and programs, a major thrust has been that the industrial sector was to play a "leading role," growing more rapidly than GNP as a whole and absorbing Immigrant labor from the rural sector. This was seen to be especially important because of the prospective rapid growth of urban population, both because of the outmigration from agriculture, and because of Turkey's relatively high rate of population growth -- 2.5 percent annually. ${ }^{1}$

All Turkish plans based their programs for the industrial sector upon a general strategy of Import substitution. Although the degree of emphasis placed upon encouraging domestic industry has varled, and attention has been given to some degree on occasion to encouraging the development of industrial exports, the chief incentives provided for the growth of the Industrial, and especially the manufacturing, sector have been through the trade regimes. Any firm or industry producing a product previously imported has been entitled to approach the government and to request that imports in the future be prohibited. This of course was tantamount to providing prohibitive levels of protection automatically to any new 1ndustry. Such requests have generally been granted, and in the event a firm's capacity appeared to be below the previous import level, the 1tem has been subject to import quotas in order to convey protection to the Industry. Firms promising to "save foreign exchange" have received favored treatment in their applications for Import licenses for investment goods and for subsidized credit.

1 In the late 1960 s and early 1970s, some Turk1sh workers migrated to work in Western Europe. However, the flow was regulated by the Turkish government and, at the peak, not more than 5 percent of the Turkish labor force was employed abroad. 
Under these Incentives, Turkish manufacturing Industry's output grew rapid1y. Table 1 gives some indicator figures. As can be seen from the fact that the share of manufacturing output and value added exceeded that of GNP, although Turkey's overall growth rate averaged in excess of 6 percent since 1960. For the perfod 1960 to 1965 , the rate of growth of manufacturing output was 6.9 percent compared with growth of GNP of 4.5 percent. While Its comparative performance has slowed down somewhat, there can be no doubt as to the manufacturing sector's role in the economy, and the emphasis given to it by Turkish policy. Th1s 1s, among other things, reflected by the fact that the share of manufacturing in total investment always exceeded the share of manufacturing in GNP, and usually by sizable amounts.

That the thrust of the growth of the manufacturing sector was orlented toward Import substitution is Indicated by the increasing share of domestic ut1lization of goods which was filled by domestic production. Thus, imports of Intermediate and Investment goods are estimated to have constituted 21 and 80 percent respectively of total consumption in 1962; by 1977, the corresponding figures were 18 and 48 percent of apparent consumption. 1

The trade regime has fluctuated in its degree of restrictiveness over the period since 1950. As already mentioned, the late 1940 s and early 1950 s were a falrly liberal pertod, while the late 1950 s were a pertod of IncreasIngly severe restrictiveness. After the devaluation of 1958 and a change in governement in 1960, the reglme was falrly liberal for a pertod of several years.

1 There has always been a considerable volume of unrecorded trade in consumer goods in Turkey, so that officlal figures overstate the degree of Import replacement. 
Table 1: INDICATORS OF MANUFACTURING SECTOR'S PERFORMANCE IN TURKEY

Share of Manufacturing

in GNP (percent)

Share of Manufacturing in

Total Investment (percent)

Share of Private Sector in Manufacturing Value Added (percent)

Average Annual Growth of Manufacturing Value Added (constant prices)

Average Annual Growth of Real GNP

Share of Imports in Manufacturing Output (percent) $b$

Consumer goods Intermediate goods Investment goods $\underline{1960} \quad \underline{1965} \quad \underline{1970} \quad \underline{1975}$

$\begin{array}{llll}13.9 & 15.6 & 16.3 & 17.0\end{array}$

$\begin{array}{llll}24^{\mathrm{a}} & 17 & 25 & 23\end{array}$

$\begin{array}{llll}58 & 65 & 64 & 68\end{array}$

$\begin{array}{lll}6.9 & 9.9 & 8.8\end{array}$

$\begin{array}{lll}4.5 & 6.6 & 7.1\end{array}$

$\begin{array}{llll}14.3 & 13.0 & 13.6 & 14.2\end{array}$

$\begin{array}{llll}1.3 & 1.0 & 1.0 & 1.1\end{array}$

$\begin{array}{llll}21.1 & 16.5 & 14.3 & 17.7\end{array}$

$\begin{array}{llll}80.5 & 69.7 & 66.4 & 48.5\end{array}$

Notes: a. Estimate is for 1963.

b. Estimates are for $1962,1967,1972$, and 1977 .

Sources: State Institute of Statistics: 1) National Income Estimates;

2) Censuses and Annual Surveys of Manufacturing Industry.

3) E. Ozotun, Turkiyenin Gelir ve Istihdam Dagilimindaki, Yapisal Degisim (Structural Change in the Distribution of Turkey's Income and Employment). Ankara, 1979, and from 4) State Planning Organization, Five Year Development Plans and 1979 Annual Program. 
By 1964, however, excess demand for forelgn exchange began to emerge and the response was to tighten import licensing. The regime became increasingly restrictive in the late 1960s, culminating in 1969-70 when there were long delays prior to receipt of foreign exchange even after licenses were issued. After a devaluation in 1970, counterspeculative flows (especially of workers' remittances from Western Europe) led to a period of about three years of relatively liberal foreign exchange licensing. Starting with the oll price increase of 1974, however, reserves were run down sharply, and the system became increasingly restrictive up to the time of writing. An interesting question, tackled below, is how these phases in the licensing system have influenced the growth and efficiency of Turkish firms.

There are several hypotheses. First, it might be that all firms have greater difficulty combining inputs efficiently in periods of import stringency. In that case, one would observe a slowdown in the rate of growth of output per unit of input across the board. Second, it might be that firms using a relatively high fraction of imported intermediate goods were more adversely affected by periods of foreign exchange difficulties than were firms relying to a greater extent upon domestically-supplied materials. In that case, there would be a differential slowdown, with firms more dependent upon imports experiencing more difficulty. ${ }^{1}$ Finally, it is plausible that new firms, starting during periods of import stringency, might behave differently from firms established during periods of relative ease. On one hand, the types of activities undertaken might be different, and on the other, the time horizon might differ substantially. In that case, one might observe different

1 To be sure, government policles might discriminate among firms, buffering some from the effects of reduced imports. This appears to have happened in Turkey especially for some segments of the chemical industry (fertilizer, insecticides, and pharmaceuticals). It has also been Turkish policy to encourage the development of Investment goods, virtually at any cost. 
behavior of growth of outputs per unit of input depending upon whether firms were started during periods of import restrictiveness or of relative ease.

One final aspect of recent Turkish economic history deserves mention. That has to do with the behavior of real wages. Starting in the early 1960s, various pressures, including a fairly liberal law protecting union rights and minimum wage legislation, served to increase the real wage in the presence of substantial urban unemployment. Table 2 gives data on the behavior of the real wage in the period since $1963 .^{1}$ As can be seen, it had more than doubled by 1976. Simultaneously, inflation was accelerating in Turkey in the late $1960 \mathrm{~s}$ and $1970 \mathrm{~s}$. Despite that, interest rates charged to industrial borrowers (under credit rationing) hardly changed. As a consequence, the increase in the real wage was less than the increase in the wage-rental ratio, as the rising rate of inflation implied a decreased cost of borrowing. ${ }^{2}$ Hence, there were strong incentives in the Turkish economy to economize on the use of labor and to substitute capital for labor, insofar as capital goods could be obtained. ${ }^{3}$

1 There is reason to believe that the real wage was either stable or rising only very slowly prior to that year.

2 The share of wages in the private manufacturing sector's domestic value added rose from .301 in 1963 to .347 in 1977.

3 A high fraction of capital goods continue to be imported into Turkey, especially after allowance is made for construction activity as an investment good (see Table 1). In addition to the above-mentioned factors affecting the relative costs of hiring capital and labor, unions in Turkey became increasingly militant in the 1970s, and employers had an incentive to substitute capital for labor to avoid production stoppages and slowdowns and costly industrial disputes. 
Table 2: NOMINAL WAGES, PRICES OF INDUSTRIAL PRODUCTS, AND REAL WAGES 1963-1976

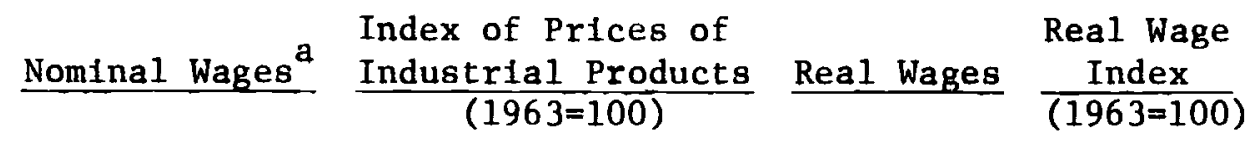

$\begin{array}{lrlll}1963 & 16.24 & 100.0 & 16.24 & 100.0 \\ 1964 & 18.00 & 103.0 & 17.48 & 107.6 \\ 1965 & 19.51 & 106.0 & 18.41 & 113.4 \\ 1966 & 21.39 & 110.2 & 19.41 & 119.5 \\ 1967 & 23.37 & 116.0 & 20.15 & 124.1 \\ 1968 & 25.94 & 117.5 & & \\ 1969 & 32.13 & 121.1 & 22.08 & 135.9 \\ 1970 & 35.32 & 131.7 & 26.53 & 163.4 \\ 1971 & 39.32 & 153.9 & 26.82 & 165.1 \\ 1972 & 43.88 & 170.7 & 25.55 & 157.3 \\ & & & 25.71 & 158.2 \\ 1973 & 54.41 & 185.0 & & \\ 1974 & 68.26 & 255.5 & 29.41 & 181.1 \\ 1975 & 85.55 & 288.8 & 26.72 & 164.5 \\ 1976 & 115.30 & 324.0 & 29.62 & 182.4 \\ & & & 35.55 & 219.1\end{array}$

Notes: a. Average wage of workers covered by Soclal Insurance. Data were interpolated for 1968-70. 
III. DATA AND PROCEDURES

Two related sets of data form the empirical basis for the estimates. The first set comes from the State Institute of Statistics which has taken Censuses and Surveys of Industries starting in 1963. The latest year for which their results are avallable is 1976 . These sources contain data on number of employees, wage b111, value of purchased inputs, value of output, Investments made by firms, and number of firms separately for public and private activities within each industrial sector employing ten or more employees. These data, combined with estimates of private and public sector capital stock provided to us by the State Planning Organization and appropriate price deflators ${ }^{1}$ complete a data set from which it is possible to infer the behavior of inputs and outputs for two-digit manufacturing industries in the private sector in Turkey. ${ }^{2}$

The second set of data originates from firms which recelved loans from the Turkish Industrial Development Bank. For those firms, data were avallable on a variety of thelr attributes (size, date of inception, precise composition of output, etc.) and also for annual investments, annual labor force and wage b111, annual purchases of raw materials and intermediate goods and inventory changes, sales, profits, depreciation, and so on. Altogether, there are $91 \mathrm{f}$ irms for which data were avallable

1 Wholesale price indices were avallable for outputs of each two-digit industry. These data were then used, in conjunction with the Turkish inputoutput tables, to obtain a weighted Input price for each sector's purchases. The same price deflators were used for two-digit industries and for the firm data described below.

2 In Krueger and Tuncer, the behavior of the private and public sectors is analyzed and contrasted, and a fuller description of the data is given. 
on a reliable basis for a period of more than five years. ${ }^{1}$ since there was credit rationing in Turkey, there is some presumption that borrowers from the Industrial Development Bank were firms of above-average quality, according to the criteria used by the Bank for its lending.

On the basis of these data, it was possible to compute an estimated capital stock for each firm using perpetual inventory techniques. Doing so was judged better than using balance sheet estimates (which were also available) since the latter made no allowance for price level changes in their capital stock in the context of a high rate of inflation as reflected in Table 2. Depreciation rates were estimated from American engineering data found in Park, ${ }^{2}$ and then scaled to equal the State Planning Organization's estimate of the average rate for all manufacturing. Investment deflators available from the State Planning Organization were first employed to convert nominal investment into constant-price estimates of additions to capital stock. Investment in a given year was treated as becoming effective capital only at the beginning of the following year. ${ }^{3}$ Period t-1's capital stock was depreciated, and then real investment in t-1 was added to obtain capital stock in period $t$.

1 Interviews were held with more than a quarter of the firms, which provided a check on the reliability of the data, and also provided additional information on characteristics of firms and their management.

2 It is an interesting question whether one should a priori expect depreciation rates to be lower or higher in Turkey than in the United States. On one hand, cheaper labor should encourage more maintenance and thus a longer economic 11fe. On the other hand, poor and 1rregular materials quality, irregular supplies of electric power, and workers with less experience in the care of equipment might tend to the opposite result.

3 For some older firms, data were not available from inception. In those cases, inftial balance sheet data were converted to an estimate of real capital stock based on knowledge of the firm's history and starting date. 
In addition, data from the firms could be directly used for the number of workers. Purchased inputs, adjusted for inventory changes, were deflated to yield an estimate of material inputs. Finally, for some firms a physical. indicator of homogeneous output (e.g. tons of cement) was avallable and used to indicate output. In others, it proved preferable to take deflated sales adjusted for inventory change as the measure of output.

Thus, for both firms and industries, data were avallable on materials inputs, outputs, labor Inputs, and capital stock inputs, along with the shares of the respective factors in the value of output. To estimate the efficiency with which inputs were employed over time, an estimate was derived of the rate of total factor productivity growth for each firm and industry. An estimate of the total factor productivity growth can be derived as follows. Consider a production function for a particular Industry or sector 1 , with output denoted by $x_{1}$. Let there be m productive inputs, with the jth input $\mathrm{Vj}$. Then the production function can be written,

$$
\text { (1) } x_{1}=f\left(v_{11}, \ldots, v_{j 1}, \ldots, v_{m 1}\right)
$$

If we had full knowledge of all inputs, in effictency untts, then changes in output over time would be fully accounted for by changes in inputs:

$$
\mathrm{dx}_{i}=\mathrm{f}_{11} \mathrm{dv}_{11}+\ldots \mathrm{f}_{j 1} \mathrm{dv}_{j i}+\ldots \mathrm{f}_{\mathrm{mi}} \mathrm{dv}_{\mathrm{mi}}
$$

where $f_{f i}$ is the partial derivative of the ith production function with respect to the $j$ th input. In fact, however, there is almost always a set of unmeasured inputs, and in addition, there may be technological change in the industry. If it is Hicks-neutral, output at time $t$ is

(2) $\mathrm{x}_{1_{t}}=\mathrm{A}_{1_{t}} \mathrm{f}_{1}\left(\mathrm{v}_{11_{t}}, \ldots, \mathrm{v}_{\mathrm{j1}}, \ldots, \mathrm{v}_{\mathrm{mi}}\right)$

$A_{i_{t}}$ is then the shift parameter for the ith industry capturing the effects on output of the measured inputs and any other unknown factors contributing 
to productivity change. Define $\alpha_{j}$ as the elasticity of output of 1 with respect to inputs of factor $f$. Then one can totally differentiate (2), and rearrange terms so that:

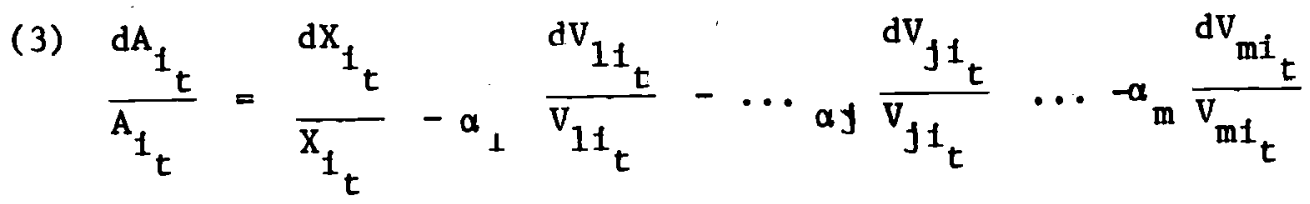

If the elasticity of output with respect to inputs is constant over a constderable range, the underlying production function must be of cobbDouglas form, although that restriction is not necessary for shorter-run analysis. In the short run, in a competitive environment where factors are pald the value of their marginal products, the elastictty of output with respect to a factor input is equal to the factor share in output. One can, therefore, estimate total factor productivity growth, dA/A, as being equal to the growth of output less the welghted average rate of the growth of Identifled Inputs, where the weights are an Index of each factor in the value of total output. ${ }^{1}$

IV. RESULTS

Basic Findings

Table 3 presents some basic results of our estimates, giving rates of growth of total factor productivity, output, capital, and labor, as

1 Using observed shares of factors in total product as welghts is strictly valld only when factors are pald the value of thelr marginal product under competitive conditions. In practice, average returns to capttal (Interest plus profits) were used to estimate capttal's share, because of the year-to-year volatility in proftts. Likewtse, it was decided not to use Divisia Indices of inputs because of the extreme volatility of shares from year to year. Rather, an average share for three midpoint years was used in the computations. For a statement as to why Divista indices should be used, see Nishimizu. In an experiment covering $20 \mathrm{ftrms}$, the $\mathrm{R}^{2}$ between our index and a Divisia index exceeded .95 . 
Table 3: PRODUCTIVITY, OUTPUT, AND INPUT GROWTH IN PRIVATE SECTOR MANUFACTURING

(continuous annual percentage rates of growth)

Private TFP Output Capital Labor

\section{Al1 Manufacturing}

Aggregate

Sample

Food Products

Aggregate

Sample

Textiles

Aggregate

Sample

Apparel and footwear

Aggregate

Sample

Wood and cork products

Aggregate

Sample

Chemicals

Aggregate

Sample

Nonmetallic minerals

Aggregate

Sample

Basic metals

Aggregate

Sample

Metal products

Aggregate

Sample

Electrical machinery

\section{Aggregate}

Sample

No sample data:

Beverages

Tobacco

Furniture and fixtures

Paper and products

Rubber products

Fur and leather products

Petroleum and coal products

Machinery except Electrical

Transport equipment
1.84

1.91

.16

.25

.84

.72

4.10

5.24

$-.55$

$-3.34$

.46

$-.04$

15.1

12.0

.72

1.61

$-.93$

2.21

21.5

15.8

25.3

14.9

18.1

7.6

1.61

$-.05$

11.8

13.3

13.1

17.1

7.8

9.0

1.41

5.76

19.8

18.8

20.1

15.8

12.5

10.7

5. 31

5.97

$-.56$

1.55

4.27

$-1.17$

$-8.80$

.62

.94
22.5

5.7

6.6

23.7

16.8

8.6

33.7

17.9

30.1
14.2

$-.3$

14.2

26.0

13.3

17.0

60.5

17.6

30.5
18.0

$-3.3$

4.7

16.7

5.1

7.8

28.1

15.2

22.7 
estimated from aggregate data and for the sample of $91 \mathrm{firms} .^{1}$ Both sets of estimates refer to private sector output only. The "aggregate" estimates, 1.e., those from the Survey of Industries and Census data, cover the period 1963 to 1976, whereas the estimates for the private sector firms cover the years for which data were avallable for each of them, weighted by their respective sales sizes over the average of 1969 to 1971.2

There are a number of interesting questions about what the relationship between firm and industry TFPG rates might be. A priori, there is no reason to expect that an industry's average growth rate will equal the average of the rates of the firms in it, either for inputs or for outputs. Indeed, one would hope that firms with above average levels of economic efficiency would expand more rapidly than average, while inefficient firms would drop out of the industry. There is also a question as to the average efficiency level of new entrants to the industry contrasted with the industry's average economic efficiency level. If Infant industry proponents are correct in their view that there is an initial period of inefficiency, this should show up in higher rates of growth

1 All estimated rates reported here and below are continuous annual rates. They are computed by estimating trends rates of growth of capital, labor, inputs, and output, from a logarithmic regression equation and then calculating total factor productivity growth rates from the computed trends. This procedure reduces the sensitivity of the estimates to fluctuations in the initial and terminal years. Unless otherwise indicated, results reported for the sample of firms pertain to output-weighted averages.

2 The estimates are made with these inputs: capital, labor, and purchased raw materials and intermediate goods. It was deemed preferable to estimate TFPG with respect to output in the Turkish economy, in part because much of import substitution has centered on replacing imported raw materials with domestic ones (generally of lower quality), and in part because we had independent checks on our output data and not on value added data. 
of total factor productivity for firms in new industries (at least after fome initial period) than in older ones. If, on the other hand, firms once in place may not alter the efficiency with which the produce (so that there is no learning by doing), but instead "embody" superior technology in their capital stock, then, one should observe a pronounced differential in rate of growth of factor productivity with industry rates of total factor productivity growth well above the observed rates of the new firms in the industry. ${ }^{1}$

The findings reported in Table 3 constitute a fairly substantial piece of evidence that neither the infant industry hypothesis nor the capital embodiment hypothesis seems to be valid, at least in the Turkish context. In most sectors, productivity growth in firms is close to, or below, the industry rate. Even in sectors where the total factor productivity growth was higher in the sample than for the two-digit industry aggregate, output growth rates for the sample were below the corresponding figures for the aggregate industry, thus suggesting that new firms were not increasing their share of industry output.

A second notable feature of the results reported in Table 3 is the relatively low level of total factory productivity growth for Turkish private manufacturing. The average continuous rate of 1.84 percent is

1 One problem, of course, is that there is no basis on which to judge the degree to which the sample of firms that we have is representative of new entrants in those industries. They were all supported by the Industrial Development Bank, which is charged with encouraging new projects, and for that reason, there is some presumption that the firms represent a better than average set of new entrants to Turkish industry. In some instances, the Industrial Development Bank financed a new project of an existing firm. Even in those instances, however, the projects financed by the Bank represented a sizable fraction of the firm's output, and could, in that sense, be regarded as representing new activity in the industry in question. 
considerably below estimated rates of 3.5 percent annually (for Norway), 1 3.66 percent annually (for Japan), ${ }^{2}$ and 2.1 percent annually (for the U.S.). ${ }^{3}$ Any hope of "closing the gap" between the developed and developing countries must surely be ephemeral as long as numbers such as these represent relative performance, regardless of what it is that total factor productivity growth estimates are really measuring.

Third, the data do not provide any support for the notion that import substitution industries, while less efficient than their counterparts in developed countries, will eventually "catch up." Among the industries on which emphasis has been placed in Turkey were chemicals, basic metals, paper and paper products, metal products, machinery, and electrical machinery. In most of these sectors, import subsitution was well under way by the late $1960^{\prime} \mathrm{s}$. None of these sectors experienced a rate of growth of total factor productivity even equaling the Turkish manufacturing average in the aggregate. For the firms in the sample, only electrical machinery surpassed the average for all firms.

A fourth feature is the virtually-universal finding that firms were expanding their capital stock much more rapldly than they were increasing their number of employees. ${ }^{4}$ of the 91 firms, only 14 increased their labor force proportionately more than they increased their their capital stock, while six firms decreased their labor force absolutely while increasing output.

$1 \quad$ See Ringstad, page 139.

2 See Nishimizu and Hulten - other estimates for Japan give even higher rates. See their Table 4.

3 See Kendrick, Table 3.

4 The labor share was nonetheless rising both for firms and for the aggregate, as was mentioned above. In light of the fact that the relative cost of employing labor more than doubled, it is remarkable that the labor share rose only from .311 to .347 - an increase of 15 percent. 
As can be seen from Table 3, for all private Turk1sh firms, the rate of Increase in employment was 7.6 percent, compared to an Increase in output of 13.5 percent and an increase in capital services of 15.9 percent. For the sample of firms, the rate of growth of capltal stack was more than twice that of employment. To be sure, Increasing output per man is highly desirable, but not when it comes about through substitution of capital for labor while individuals remain employed in pursults with substantially lower marginal products. There seems to be a 11ttle doubt that Turkish Industry, almost sector by sector and f1rm by f1rm, has substituted capital for labor to a considerable extent in response to the rising relative cost of employing labor compared to using the services of capital.

Reasons for Low Product1vity Growth

These findings ralse more questions than they answer. If Indeed Turk1sh performance was so poor, why was it poor? What accounts for the results? One set of estimates for a particular country cannot yleld enough data for definitive analysis. Unt11 much more is learned about patterns of total factor productivity growth across countries and industries, any analysis must remain suggestive. Nonetheless, the findings for Turkey are broadly conslstent with several hypotheses that have been put forth in the trade and development 11terature.

One plausible hypothesis, to which the data lend some support, is that it is the policles adopted under an import substitution strategy which have led to the relatively poor perfromance of Turkish manufacturing Industry. In particular, high levels of protection have tended to give Individual producers relatively secure shares of the domestic market, and few incentives to attempt to reduce costs. Rewards have been for producing at all costs, rather than for minimizing costs of production. Regulations governing 
conditions of production have also tended to discourage many attempts at effictency.

The data from our sample can never substantlate this hypothesis, but they may go some way toward 1t. There are several pleces of evidence: 1) analysis of TFPG of firms by year of entry reveals an Interesting correlation between their performance and the economic conditions obtaining at the tIme they entered; 2) the overall rates of TFPG across fIrms vary quite markedly with the state of the trade and payments regime over time; 3) data on rates of productivity growth by size of firm do not suggest any tendency for efflclency gains to be related to Increased shares; 4) there is a very low correlation between TFPG and profit rates; and 5) observed relative price behavior in Turkey suggests that the 1Ink between domestic and International price movements was very weak.

Table 4 gives the rates of growth of total factor productivity, output, and capttal and labor Inputa for firms classifled according to the date at which they were founded. These dates are, to be sure, sometimes somewhat misleading as some old family firms shifted production into modern, Import substitution 1 ines under the same name, but that appears to have been the exception rather than the rule. As can be seen, there were $16 \mathrm{firms}$ founded before 1950. Their output-welghted average total factor productivity growth rate was 4.57 percent over the perfod it was measured (which never started before 1955 and often did not start unt11 1960). Firms started in the pertods of severe Import restriction, 1955 to 1959 and 1965 to 1969, have generally been poor performers; the 1965-69 group had negative total factor productivity growth on average, and the group ten years older expertenced TFPG of less than one percent. Thus, the notion set forth in Section II, that periods 
of Import stringency may encourage the emergence of a different type of entrepreneur than firms started during the more liberal perlods, gets some support from the Turk1sh data.

Table 4: STARTING DATE OF FIRM, OUTPUT, INPUT, AND PRODUCTIVITY GROWTH (continuous annual rates)

Date firm started: No. of Firms Mean MFP Median Output Capital Labor

$\begin{array}{lrrrrrr}\text { Before } 1950 & 16 & 4.57 & 1.32 & 8.55 & 8.97 & 1.79 \\ 1950 \text { to } 1954 & 13 & 1.46 & 1.88 & 9.97 & 16.14 & 5.26 \\ 1955 \text { to } 1959 & 22 & .81 & 1.58 & 9.37 & 12.56 & 5.25 \\ 1960 \text { to } 1964 & 20 & 2.66 & 2.16 & 16.44 & 10.06 & 16.51 \\ 1965 \text { to } 1969 & 17 & -1.01 & .18 & 9.81 & 12.79 & 9.78\end{array}$

Note: Data are output-weighted averages. The age of one firm was unknown, and only two firms were started after 1969.

The second plece of evidence, namely the fluctuation in total factor productivity growth with the restrictiveness of the trade regime, is at best suggestive. As mentioned above, the estimates are sensitive to cholce of Intital and terminal years, a problem that can be resolved by use of estimated trends when considering a sizable number of years. When moving to consideration of shorter time pertods, time trends become less meaningful, and Inttial and terminal points must be used, with the greater volatility they give to the estimates. The best that can be done 18 to compute rates from pairs of moving averages, taking three-year perlods. These are given, for output-welghted and simple averages of the data, for all the firms in the sample and for the firms in three specific industrles, for the years from 1957-60 onward In Table $5^{1}$

1 Thus, the rate given for $1957-60$ refers to the rate computed from the average of 1957-59 and 1958-60. Patterns for other sectors are not dissimilar to those presented in Table 5. They are not presented due to space limitations, although it should also be noted that, with a few exceptions, the number of firms drops off sharply in some sectors, espectally for the early time period. 
Table 5: TFPG OVER TIME

A. A11 Firms

\begin{tabular}{|c|c|c|c|c|c|c|}
\hline Dates & \multicolumn{2}{|c|}{ No. of Firms } & \multicolumn{2}{|c|}{$\begin{array}{c}\text { UnweIghted } \\
\text { TFPG } \\
\end{array}$} & \multicolumn{2}{|c|}{$\begin{array}{c}\text { Weighted } \\
\text { TFPG } \\
\end{array}$} \\
\hline $\begin{array}{l}1957-60 \\
1958-61 \\
1959-62 \\
1960-63 \\
1961-64 \\
1962-65\end{array}$ & & $\begin{array}{r}6 \\
7 \\
10 \\
12 \\
21 \\
27\end{array}$ & & $\begin{array}{l}.25 \\
.91 \\
.62 \\
.82 \\
.31 \\
.92\end{array}$ & \multicolumn{2}{|l|}{$\begin{array}{r}-1.55 \\
4.95 \\
5.68 \\
11.11 \\
6.11 \\
3.67\end{array}$} \\
\hline $\begin{array}{l}1963-66 \\
1964-67 \\
1965-68 \\
1966-69 \\
1967-70 \\
1968-71\end{array}$ & & $\begin{array}{l}38 \\
42 \\
57 \\
67 \\
73 \\
79\end{array}$ & & $\begin{array}{l}.59 \\
.70 \\
.60 \\
.24 \\
.51 \\
.55\end{array}$ & $\begin{array}{r}1.42 \\
.69 \\
-1.79 \\
9.74 \\
3.08 \\
4.40\end{array}$ & \\
\hline $\begin{array}{l}1969-72 \\
1970-73 \\
1971-74 \\
1972-75 \\
1973-76 \\
1974-77\end{array}$ & \multicolumn{2}{|r|}{$\begin{array}{l}83 \\
84 \\
86 \\
86 \\
55 \\
19\end{array}$} & & $\begin{array}{l}.39 \\
.62 \\
.41 \\
.11 \\
.153 \\
.37\end{array}$ & $\begin{array}{r}-5.52 \\
.69 \\
-.22 \\
2.03 \\
-5.82 \\
5.74\end{array}$ & \\
\hline \multirow[b]{2}{*}{ Dates } & \multicolumn{2}{|c|}{ Text1les } & $\begin{array}{l}\text { entat Ive } \\
\text { Chem: }\end{array}$ & $\begin{array}{l}\text { Sector } \\
\text { Lcals }\end{array}$ & \multicolumn{2}{|c|}{ Basic metalo } \\
\hline & $\#$ Firms & TFP & \# Firms & TFP & \# Firms & TFP \\
\hline $\begin{array}{l}1957-60 \\
1958-61 \\
1959-62 \\
1960-63 \\
1961-64 \\
1962-65\end{array}$ & $\begin{array}{l}1 \\
1 \\
1 \\
1 \\
4 \\
4\end{array}$ & $\begin{array}{r}-7.25 \\
-7.69 \\
-11.53 \\
4.04 \\
5.78 \\
7.75\end{array}$ & $\begin{array}{l}1 \\
1 \\
1 \\
1 \\
2 \\
2\end{array}$ & $\begin{array}{r}-2.59 \\
1.22 \\
1.01 \\
-6.44 \\
13.64 \\
27.79\end{array}$ & $\begin{array}{l}0 \\
0 \\
0 \\
1 \\
1 \\
2\end{array}$ & $\begin{array}{r}-\infty \\
-\infty \\
-- \\
32.59 \\
9.92 \\
5.57\end{array}$ \\
\hline $\begin{array}{l}1963-66 \\
1964-67 \\
1965-68 \\
1966-69 \\
1967-70 \\
1968-71\end{array}$ & $\begin{array}{r}8 \\
10 \\
16 \\
19 \\
20 \\
21\end{array}$ & $\begin{array}{r}-1.24 \\
3.41 \\
3.53 \\
-.55 \\
-3.43 \\
.61\end{array}$ & $\begin{array}{l}3 \\
3 \\
3 \\
5 \\
6 \\
7\end{array}$ & $\begin{array}{r}-8.30 \\
7.42 \\
6.04 \\
7.01 \\
2.30 \\
-2.13\end{array}$ & $\begin{array}{l}4 \\
5 \\
5 \\
6 \\
6 \\
6\end{array}$ & $\begin{array}{l}-1.20 \\
-1.05 \\
-0.53 \\
-4.08 \\
-5.38 \\
-1.27\end{array}$ \\
\hline $\begin{array}{l}1969-72 \\
1970-73 \\
1971-74 \\
1972-75 \\
1973-76\end{array}$ & $\begin{array}{l}20 \\
20 \\
20 \\
19 \\
12\end{array}$ & $\begin{array}{r}-1.07 \\
1.66 \\
-2.58 \\
3.39 \\
-\quad .60\end{array}$ & $\begin{array}{l}7 \\
7 \\
8 \\
7 \\
5\end{array}$ & $\begin{array}{r}-7.56 \\
-.60 \\
3.80 \\
10.02 \\
2.47\end{array}$ & $\begin{array}{l}7 \\
7 \\
7 \\
7 \\
6\end{array}$ & $\begin{array}{r}5.22 \\
5.97 \\
9.69 \\
-3.75 \\
2.68\end{array}$ \\
\hline
\end{tabular}

Note: TFPG rat10s for the three sectors are output-welghted averages of ratios for Individual firms in the period indicated. 
The rapid total factor productivity growth in the early 1960s is readily evident in both the weighted and the unwelghted averages for all firms and for the three Individual secotors indicated in the table. The decline in productivity growth in the late 1960s, the perfod when forelgn exchange I1censes became scarce, is also apparent. It should be observed that the performance in the late 1960 s was not dissimilar to that in the late 1950s -- both periods of extreme difficulty for firms attempting to obtain permits to Import raw materials, Intermedlate goods, and spare parts.

It may also be noted that, in addition to exhibiting fluctuations in productivity growth rates which seem to colnclde with phases of the forelgn exchange cycle, there appears to be something of a deceleration in the rate of total factor productivity growth, with a higher average rate in the early $1960 \mathrm{~s}$ than in the late 1960s, and; after an Inftlal burst in the ear1y 1970s, further deceleration. Th1s may be attributed to the "exhaustion of easy Import substitution," or to other phenomena. ${ }^{1}$

Yet a third plece of evidence comes from examination of the pattern of total factor productivity growth related to the size of firms. Table 6 gives the data. For total factor productivity and for output, average annual continuous rates of growth are given as a simple average and weighted by Individual firms' outputs. There does not appear to have been a signiflcant difference between simple and output-weighted rates of total factor productivity growth. In general, one would expect that, in a

1 It was mentloned above that import-dependent f1rms might experience more of a slowdown in productivity growth than less import-using firms. Our data were Inconclusive on this point, with some tendency in that direction for 1967-70, but less so for 1973-76. The possibllity of selective treatment of Individual industries may account for this, or 1t may be that the effects of restrictive Import licensing are all-pervasive. 
Table 6: SIZE, TFP AND OUTPUT GROWTH

(average annual continuous rates)

Size of Firm

("\# of employees)

10-50

51-100

101-150

151-200

201-250

$251-500$

501-800

Over 800

Total Sample
Total Factor Productivity Growth

S1mple Average Output We1ghted

$-.29$

$-4.83$

.78

.18

1.27

10.11

4.59

.76

1.91
Output Growth Rate

S Imple Average Output Weighted

12.38

8.98

11.29

13.82

11.47

17.49

11.34

9.35

11.98
11.65

2.13

11.51

12.98

11.14

16.91

9.48

10.29

11.13 
competitive environment firms with higher rates of total factor productivity growth would expand their output more rapidly than firms with slower total factor productivity growth. ${ }^{1}$ This, too, does not appear to have happened with any regularfty. Large firms experlenced relatively slow productivity growth, and yet output from that group grew at a welghted rate of 10 percent annually, which was slightly above the rate of growth of output for firms in the 500-800 employee size group.

The pattern that emerges from all of the above would seem to suggest 11ttle correlation between rates of growth of output per untt of input and other varlables. One hypothesis is that the fallure of these relationships to hold is attributable to the lack of incentive for Increasing efficlency within the Turkish context, relative to the Incentive for increasing output, virtually "at all costs" (given the protected environment In which firms were producing and the generally excess-demand nature of the economy). Some corroboration for this hypothesis is given by a simple regression estimate, of the form:

$$
\frac{\mathrm{P}}{\mathrm{K}}=\mathrm{a}_{0}+\mathrm{a}_{1} \mathrm{TG}+\mathrm{a}_{2} \frac{\mathrm{dQ}}{\mathrm{Q}}+\mathrm{u}
$$

where $P / K$ is the average rate of profit per unit of capltal employed by the firm, TG is the computed rate of total factor productivity growth, and $d Q / Q$ is the rate of growth of output of the firm. If Incentives in Turkey are for entrepreneurs to concentrate thetr efforts on Increasing

1 Each firm is classifled in one size category, based on its number of employees in 1969-1970. Therefore, entry of smaller firms into new size categories is not a factor blasing these results. 
output rather than for reducing costs, ${ }^{1}$ this should be reflected by a positive coeffictent for $a_{2}$ and a negative one (or at least one substantially smaller in value) for $a_{1}$. The estlmated regression 1s:

$$
\mathrm{P} / \mathrm{K}=.315-\underset{(.96)}{1.996 \mathrm{TG}}+\underset{(.55)}{2.11 \mathrm{dQ} / \mathrm{Q}} \quad \mathrm{R}^{2}=.39
$$

The elasticity of profits with respect to the output growth rate at the mean was .45 , whlle the elasticity of profits with respect to total factor productivity growth was -.25 .

The final plece of evidence concerns the behavior of relative prices In Turkey and abroad. In a competitive market, with International prices given and 1iberalized trade, domestic prices of outputs of different commoditles would not alter. In a closed economy, however, when firms have monopoly power, one would expect that there would be some relationship between rates of total factor productivity growth and rates of (relative) price Increase.

Table 7 glves the data. For sectors for which American and Turkish price Indexes were avallable and approximately comparable, rat los were taken of the relative price Increases between Turkey and the UnIted States over the perlod from 1963-69 (during which time the exchange rate vis-a-vis the dollar and the TL was fixed) and for the period 1971-76 (during which

1 It can, of course, be argued that there are always incentives for doing both. A difficulty is that there are constraints on avallability of Import licenses, credit, and other resources within Turkey. Insofar as avallable resources are allocated to cost reductions, as for example by Importing different machinery, they may be diverted from output increases. The same may be true for managertal time. Some interviewees claimed that they had not pald any attention to increasing productivity at least until very recently. One firm with a relatively poor record of productivity growth indicated in interview that, after 1976 it was decided that output would not expand for a while, so attention should shift to reducing costs. The result was a small increase in output, sale of several parts of the plant and equipment, and a reduction in half of the workforce, with a 20 percent reduction in energy Inputs and materials savings. 
Table 7: RATES OF TOTAL FACTOR PRODUCTIVITY GROWTH AND RELATIVE PRICE CHANGES

\begin{tabular}{|c|c|c|c|c|}
\hline \multirow[b]{2}{*}{ Sector } & \multicolumn{2}{|c|}{ 1963-1969 } & \multicolumn{2}{|c|}{ 1971-1976 } \\
\hline & $\begin{array}{l}\text { Ratio of } \\
1969 \text { to } \\
1963 \\
\text { Relative } \\
\text { Prices } \\
\end{array}$ & $\begin{array}{c}\text { 1963-1970 } \\
\text { Total Factor } \\
\text { Productivity } \\
\text { Growth } \\
\text { Rate } \\
\end{array}$ & $\begin{array}{l}\text { Ratio of } \\
1976 \text { to } \\
1971 \\
\text { Relative } \\
\text { Prices } \\
\end{array}$ & $\begin{array}{c}1970-1976 \\
\text { Total Factor } \\
\text { Productivity } \\
\text { Growth } \\
\text { Rate } \\
\end{array}$ \\
\hline $\begin{array}{l}\text { Food products } \\
\text { Textiles } \\
\text { Wood and cork } \\
\text { Furniture and } \\
\text { flxtures }\end{array}$ & $\begin{array}{l}1.11 \\
1.02 \\
1.05 \\
1.07\end{array}$ & $\begin{array}{l}.09 \\
3.02 \\
1.34 \\
2.67\end{array}$ & $\begin{array}{l}1.18 \\
1.25 \\
1.34 \\
1.14\end{array}$ & $\begin{array}{l}-.97 \\
-1.78 \\
-2.89 \\
-1.37\end{array}$ \\
\hline $\begin{array}{l}\text { Paper and } \\
\text { products }\end{array}$ & 1.05 & 2.44 & 1.01 & 2.03 \\
\hline $\begin{array}{l}\text { Fur and leather } \\
\text { products } \\
\text { Rubber products } \\
\text { Chemicals } \\
\text { Petroleum and } \\
\text { coal }\end{array}$ & $\begin{array}{r}.91 \\
1.02 \\
-\end{array}$ & $\begin{array}{l}5.90 \\
2.94 \\
-\end{array}$ & $\begin{array}{r}.88 \\
.93 \\
.68\end{array}$ & $\begin{array}{r}4.84 \\
-1.09 \\
-5.38\end{array}$ \\
\hline $\begin{array}{c}\text { Nonmetallic } \\
\text { minerals } \\
\text { Basic metals } \\
\text { and metal } \\
\text { products }\end{array}$ & $\begin{array}{l}1.14 \\
1.09\end{array}$ & $\begin{array}{r}2.18 \\
-\quad .02\end{array}$ & 1.19 & $\begin{array}{r}-1.84 \\
2.15\end{array}$ \\
\hline $\begin{array}{l}\text { Machinery } \\
\text { Transport } \\
\text { equipment }\end{array}$ & $\begin{array}{l}1.09 \\
1.16\end{array}$ & $\begin{array}{r}4.77 \\
-3.65\end{array}$ & $\begin{array}{l}1.17 \\
1.30\end{array}$ & $\begin{array}{r}.57 \\
7.04\end{array}$ \\
\hline
\end{tabular}


perfod the exchange rate depreclated from TL 15 per dollar In 1970 to TL 16.7 per dollar In 1976). Ratios of the rates of price Increase in the U.S. and In Turkey are given in the first and third colums. For nonmetallic mineralo, for example, the American price rose by 10.9 percent from 1963 to 1969, wh1le the Turk1sh price Index rose 25.9 percent. Thus, In 1969, the Turkish price of nonmetallic minerals was 13 percent h1gher, relative to the American price, than it had been In $1963^{1}$ Although western European countrles are at least as Important as the United States In Turkey's trade, it is 11kely that American and European prices of tradables move fairly closely together, and that taking American prices does not Introduce significant distortions into the comparison. As can be seen, there was considerable relative price fluctuation between the two countries, attesting to the fact that the trade regime effectively closes off the economy from International relative price movements. Moreover, Inspection of rates of total factor productivity growth Indicate that there has not, In general, been a very close link between domestic price behavior and rates of total factor productivity growth. Thus, transport equipment had a relatively high rate of Increase of output per unit of input in the 1970 , but 1ts domestic relative price Increased sharply compared to the International price. Only for rubber products does a high rate of total factor productivity growth appear to have been accompanied by a pronounced decline in the relative price in Turkey.

1 The year 1970 is not included because that was a year of devaluation and relative price realignment in the Turkish economy. 
None of these pleces of evidence in themselves constitutes proof that the low rate of total factor productivity growth in Turkish manufacturing was assoclated with the Incentives provided by the trade and payments regime. They are, however, strongly suggest1ve of that conclusion.

\section{CONCLUSIONS}

Estimating total factor productivity growth for firms and Industries provides a useful tool for analyzing some aspects of the economic growth of developing sountries. Certalnly, increasing outputs per untt of (phys1cal, quality unadjusted) Input offers hope of "closing the gap" and Increasing real incomes that is not feastble in 1ts absence. However, the relationsh1ps between m1cro and macroeconomic aspects of total factor productivity growth are not sufficlently well understood for any firm concluslons to be drawn about overall economic growth unt1l much further work 1s undertaken.

For Turk1sh manufacturing, however, the est1mates presented In this paper provide some falrly compelling evidence that the dynamic arguments used In support of the Turklsh Import substitution strategy have not in fact had an 1dentifiable empirical basis. Whether the alleged dynamic component is a result of externalities, economies to scale, Indivisibilities, improved quality of the labor force, learning by doing, or other phenomena It should be reflected In Increased output per unlt of Input, a phenomenon that has happened more slowly in Turk1sh manufacturing than in those industrialized countries for which estimates are avallable.

A final word of caution 18 in order, however. Much as Increasing output per unit of input 18 undoubtedly desirable, proof that productivity is rising is not per se evidence that the activity in question is economic. 
Indeed, as we have shown elsewhere (Krueger and Tuncer), output per unft of input appears to have Increased somewhat faster in Turkibh public enterprises in the manufacturing sector than in private firms, and yet there is every evidence that Inputs per unit of output are substantially higher in the public sector.

The obvious policy conclusion is that total factor productivity growth for Turkish manufacturing would have been higher if public sector enterprises (w1th more rapld growth) had grown more slowly and the private sector more rapldiy: shifting resources to more efficlent uses may increase output per unit of Input more rapidly than increasing output per unit of input within activities. Obviously, an optimal set of economic policles achleves equal efficlency in all cases and simultaneously encourages rapld growth of factor productivity. 


\section{REFERENCES}

Arrow, Kenneth J., "The Economlc Implications of Learning by Doing," Review of Economic Studies, 29, June 1962, pp. 155-73.

Baldwin, Robert E., "The Case Against Infant-Industry Tariff Protection," Journal of Political Economy, 77 (3), May/June 1969, pp. 295-305.

Bhagwat1, Jagdish, Forelgn Trade Regimes and Economic Development: Anatomy and Consequences of Exchange Control Regimes, Ballinger Publishing Co., Cambridge, MA. (for the National Bureau of Economic Research), 1978.

Kendrick, John W., "Productivity Trends and the Reverse Slowdown: Historical Perspective, Causal Factors, and Policy Options," in W. Fellner (profect director), Contemporary Economic Problems, American Enterprise Institute, Washington 1979.

Krueger, Anne 0., Forelgn Trade Regimes and Economic Development: Turkey, Columbia University Press (for the National Bureau of Economic Research), 1974.

Krueger, Anne 0. and Tuncer, Baran, "Estimating Total Factor Productivity Growth In a Developing Country," forthcoming.

Nishimizu, M., "On the Methodology and Importance of the Measurement of Total Factor Productivity Change: The State of the Art," mimeograph, October 1979.

Nishimizu, M,. and Hulten, Charles R., "The Sources of Japanese Economic Growth: 1955-71," Review of Economics and Stat 1stics, August 1978.

Park, W.R., Cost Engineering Analysis, John Wiley and Sons, New York 1973, Table 26 .

Ringstad, V., Est1mating Production Functions and Technical Changes from Microdata, Stat1stisk Sentralbyra 1971. 